\title{
First evaluation of fruit quality of some new and old sour cherry cultivars in Hungarian climatic condition
}

\author{
Davarynejad, GH. ${ }^{1}$, Nyéki J. ${ }^{2}$, Szabó, T. ${ }^{3}$, Tornyai, J. ${ }^{2}$, Soltész M. ${ }^{3}$, Aryanpooya, Z. ${ }^{1}$ \& Szabó Z. ${ }^{2}$ \\ ${ }^{1}$ Horticultural Department, Ferdowsi University of Mashhad, Iran \\ ${ }^{2}$ Institute for Research and Development, Debrecen University, Hungary \\ ${ }^{3}$ Fruit Research and Extension Institute, Újfehértó, Hungary \\ ${ }^{4}$ University of Corvinus, Budapest, Hungary
}

\begin{abstract}
Summary: Indeed, in the last decade a large number of new sour cherry cultivars with new notable flavor characteristics have been released. There is no enough information related to qualitative characteristics which consistently segregated based on their predominant sensory characteristics. The present study carried out at tow consecutive years (2008 and 2009) and examined some qualitative characters which are the main importance in the specialty cherries trade, The main objective was to determine fruits quality of Érdi bőtermő, Oblacsinszka, Debreceni bőtermő, Csengődi, Pándy 279, Éva, Kántorjánosi, Újfehértói fürtös and Petri sour cherry cultivars. Changes observed in major characteristics such as fruit detachment force, width, length, weight, peduncle length, flesh firmness, brix, citric acid, Suger/acid ratio and pit weigh. While observed no change in flesh/pit ratio and Coordinate of colour $\left(\mathrm{X}^{*}, \mathrm{y}^{*}, \mathrm{x}^{*}\right)$, hue angle and chroma value, in different years. In all measured factors, there was significant difference between selected cultivars of sour cherry fruit. Debreceni bőtermő showed higher values of fruit detachment force in 2008, while had the lover of fruit detachment force in 2009. Fruit firmness of "Érdi bőtermő" were monitored at lover value in both 2-year.
\end{abstract}

Key words: fruit detachment force, firmness, fruit colour, consumer acceptance tests, trained panel, soluble solids concentration, acidity

\section{Introduction}

Processing units, consumers and fruit growers need a lot of Information about physical and chemical properties of sour cherry fruits, especially from a large number of new sour cherry cultivars with new notable flavor characteristics which have been released in the last decade. This information is very important for understanding the behavior of the product during the harvesting, transporting, sorting, packaging and storage processing. According to Hesse (1973) fruit taste and sweetness are well correlated with quality by consumers.

Many Processing units do not accept fruits with stems because of the time and expense involved in removing the stems (Mitra et al., 1991).

Indeed, each cultivar of sour cherry has unique characteristics that undergo sensory evaluation by the consumer and processing units. The use of panels test can be an important part of fruit quality assessment. The yield and fruit quality of sour cherries are extremely variable from year to year. However we are unable to improve the quality of sour cherries after harvesting, but there are some properties which is very important as indicators of sour cherry fruits quality and maturity, the same as appearance (skin colour and freedom from defects), texture, flesh firmness, sugar and acid ratio are key factors that determine high-quality fresh fruits, seed and flesh ratio, flavour and volatile compounds, ease of separation of the fruit from the tree and peduncle and brix. Sour cherry fruits are the same as sweet cherry fruits, but sour cherries generally have lower sugars and higher total acid contents, and are generally red in color and used for processing (Holb and Schnabel, 2005; Ansari and Davarynejad, 2008). Traditionally, color change and soluble solids content were the most reliable indices. However, fruit removal force has been used more recently, and is more reliable, that this is measured by a pull gauge, which pulls the fruit from the pedicle. Fruit acid level is important for sour cherries (Rieger, 2003). In general, for determining optimum harvest date, any fruit that leaves the pit attached to the stem when it is pulled is not ready for harvest.

The color development is the best guide, though it varies with the cultivar and the purpose for which the fruit will be used. For example, color of 'Lambert' for fresh fruit shipment should be somewhat maroon, optimum for fresh market should be dark color and for canning fully mature (Teskey and Shoemaker, 1972).

High brix (SSC) with high fruits consumer preference and or acceptance for different commodities (Robertson and Meridith, 1989; Rodan, 1988; Gorini and Lasorella, 1990); other quality attributes may also be important in consumer acceptance (Kader, 1999). Minimum quality standards based on SSC to assure consumer satisfaction have been proposed 
for 'Bing' (Cliff et al., 1996; Dever et al., 1996; Guyer et al., 1993; Schotzko, 1993) and 'Ranier' (Drake and Fellman, 1987) cherries. The relationship between SSC and TA and visual appearance plays an important role in consumer acceptance as it is reported for other commodities such as citrus (Pehrson and Ivans, 1988); table grapes (Crisosto and Crisosto, 2002); kiwifruit (Crisosto and Crisosto, 2001) and mango (Malundo et al., 2001). Therefore, it is important to understand the potential involvement of TA in cherry consumer acceptance prior to proposing a minimum quality standard. This relationship between SSC and TA, and consumer acceptance may also be cultivar specific and even related to ethnic group. Chang et al. (1987) found that fruit weight was important factor in yield of sour cherry.

A gradual reduction of the acid content takes place during the ripening of cherries, which is different in various cultivars. Cherries gain in weight from the time they begin to mature until the fruit was fully ripe. Fruits of early pickings of cherries do not taste well. Late picked fruits may be either very sweet or insipid. So taste of the fruit may guide the time of picking. Early picked cherries, in general, are small, more or less flat in taste, soft in texture and subsequently display shriveling. Those picked at a right stage have better size, colour, and appearance, firmer, more aromatic, tastier, good sugar/acid ratio and with a pronounced cherry flavor. Those picked overripe show some discoloration when canned. (Mitra et al., 1991).

Fresh firmness is another important attribute of sour cherries and it is often used for fruit quality assessment, besides color, quality consistency for cherries destined for the fresh market (Girared and Kopp. 1998).

There is no standard degree of maturity for picking the cherries. Flavor and over-all color as determined by sampling a few fruits of each variety, furnish the best guides for time to harvest. Cherries, like other stone fruits, increase in size until ripe and should be left on the tree as long as feasible to attain the maximum poundage per tree. Investigations show that the final increase in fruit size may be 35 percent from the time they can first be picked until full maturity.

The objectives of this study were to investigate differences between the cultivars and changes in fruit quality of sour cherry fruits for processing and fresh consumption also to improve the organoleptic quality of sour cherry cultivars, according to consumer acceptance with the aim of producing genotypes with excellent taste, and balanced sugar/acid ratios.

\section{Material and methods}

\section{Fruit source}

Nine sour cherry cultivars grafted on Prunnus mahleb include: Érdi bőtermő, Oblacsinszka, Debreceni bőtermő, Csengődi, Kántorjánosi, Újfehértói fürtös, Éva, Pándy279 and Petri sour cherry (Prunus cerasus L.) were used in this study. All were cultivated on a sour cherry collection at the fruit Research and Extension Center for Fruit Growing,
Újfehértó, of Debrecen Eastern north part of Hungary. The study area lies in $38^{\circ} 10^{\prime}$ latitude and $30^{\circ} 37^{\prime}$ longitude, and altitude is $1,050 \mathrm{~m}$. The annual average temperature was $9.5^{\circ} \mathrm{C}$, and the annual rainfall over last 50 years was $583 \mathrm{~mm}$. The average temperature and amount of rainfall in growing season of 2008 was 14.74 centigrade degree and $396 \mathrm{~mm}$ respectively while these parameter in 2009 changes to 15.34 and 187. It means growing season of 2009 was warmer and the rain fall was 2 time less than 2008 .

\section{Quality evaluations}

Fruits were harvested by hand at eating maturity stages. Fruit weight(FW) and pit weight (PW), fruit diameter (FD), fruit height $(\mathrm{FH})$, flesh firmness $(\mathrm{FF})$, skin color (SC) and brix (soluble solids concentration) (SSC) measured at harvest on $200 \mathrm{~g}$ of fruits per combinations. FD was measured by digital calliper (Mitutoyo IP66, 500-623, Japan) by taking the mean of the largest and smallest diameter of the fruit.

Fruit firmness $(\mathrm{KPa} / \mathrm{mm})$ was determined on 3 point of each fruit and totally from 50 fruits using a portable instrument nondestructive election penetrometr Poion organizer Model LZ by head $4 \mathrm{~mm}$.

For Brix and acid measurements, The pits were removed from the fruits. Each cultivar was divided into three groups, each group consisting about $200 \mathrm{~g}$ sour cherry. The fruits were stoned and homogenized using Braun household mixer. The homogenate samples were used for brix and acid content. Brix and acid analyses were performed on five subsamples.

$\operatorname{Brix}(\%)$ was measured by digital refrectometr Atago Pr 201 Japan and citric acid content (\%) measured by pocket refrectometr, Atago (0-10g/100g).

The skin color from 3 point of each fruit and totally from 50 fruits was measured by CR-200 chromameter (Minolta, Japan) which displayed in $\mathrm{Y}^{*}, \mathrm{x}^{*}$, and $\mathrm{y}^{*}$ values that represents light-dark spectrum, the green-red spectrum and the blue-yellow spectrum. C* (chroma), were calculated by using the following equation: $\mathrm{C}^{*}=\left(\mathrm{x}^{* 2}+\mathrm{y}^{* 2}\right)^{1 / 2}, \mathrm{~h} *$ (hue angle) was calculated by using the following equation: $\mathrm{h}^{*}=\arctan (\mathrm{y} * / \mathrm{x} *)$.

Consumer degree of liking measured on 0-9 point hedonic scale (0, extremely dislike, 5, neither like nor dislike and 9, like extremely) or (B) percentage consumer acceptance.

\section{Statistical analysis}

All data in the present study were subjected by analysis of variance (ANOVA) and mean were separated by Duncan's multiple range tests. The figures and tables are performed by the Excel program.

\section{Result and discussion}

The mean values of the assessed characteristics and theirs spans in 2008 and 2009 years are given in Table 1. The fruit 
Table1. Mean values of assessed characteristics and their span in 2008 and 2009

\begin{tabular}{|c|c|c|c|}
\hline \multirow{2}{*}{ Characteristics } & \multicolumn{2}{|c|}{ Means } & \multirow{2}{*}{$\begin{array}{c}\text { Significant } \\
\text { level }\end{array}$} \\
\hline & 2008 & 2009 & \\
\hline Fruit detachment force $(\mathrm{N})$ & $3.42^{\mathrm{a}}$ & $2.14^{\mathrm{b}}$ & $* *$ \\
\hline Fruit width (mm) & $20.85^{b}$ & $22.69^{\mathrm{a}}$ & $* *$ \\
\hline Fruit thickness (mm) & $22.75^{\mathrm{a}}$ & $19.96^{\mathrm{b}}$ & $* *$ \\
\hline Fruit length (mm) & $20.03^{\mathrm{a}}$ & $19.29^{\mathrm{b}}$ & $* *$ \\
\hline fruit weight (g) & $5.82^{\mathrm{a}}$ & $5.65^{b}$ & $* *$ \\
\hline Peduncle length (mm) & $43.49^{\mathrm{a}}$ & $40.99^{\mathrm{b}}$ & $* *$ \\
\hline Firmness $\left(\mathrm{kP} / \mathrm{mm}^{2}\right)$ & $474.54^{\mathrm{b}}$ & $490.83^{\mathrm{a}}$ & $*$ \\
\hline citric acid $\%$ & $1.77^{\mathrm{a}}$ & $1.22^{\mathrm{b}}$ & $* *$ \\
\hline Brix \% & $16.60^{\mathrm{b}}$ & $17.12^{\mathrm{a}}$ & $* *$ \\
\hline pit weigh (g) & $0.40^{\mathrm{a}}$ & $0.38^{\mathrm{b}}$ & $* *$ \\
\hline Flesh/pit & $13.56^{\mathrm{a}}$ & $13.82^{\mathrm{a}}$ & Ns \\
\hline Sugar/acid & $9.66^{b}$ & $14.79^{\mathrm{a}}$ & $* *$ \\
\hline \multicolumn{4}{|l|}{ Colour coordinate } \\
\hline $\mathrm{Y}^{*}$ & $5.19^{\mathrm{a}}$ & $5.35^{\mathrm{a}}$ & Ns \\
\hline $\mathrm{x}^{*}$ & $0.36^{\mathrm{a}}$ & $0.35^{\mathrm{b}}$ & $* *$ \\
\hline$y^{*}$ & $0.31^{\mathrm{a}}$ & $0.31^{\mathrm{a}}$ & Ns \\
\hline Hue angle & $41.30^{\mathrm{a}}$ & $41.36^{\mathrm{a}}$ & Ns \\
\hline Chroma value & $0.47^{\mathrm{a}}$ & $0.46^{\mathrm{b}}$ & $* *$ \\
\hline
\end{tabular}

$*$, **Significant levels at $1 \%$ and $0.1 \%$ respectively. Ns: not significant. Standard deviation values in the parentheses. a-b letters indicate the statistical difference in rows.

detachment force, fruit thickness, fruit length, fruit weight, peduncle length, citric acid and pit weigh were decreased, but the fruit width, fruit firmness, brix and sugar/acid were increased in 2009 compare to 2008. In some measured properties was no significant difference such as the flesh/pit ratio, $\mathrm{Y}^{*}, \mathrm{x}^{*}, \mathrm{y}^{*}$, hue angle and chroma value. Sour cherries were smaller in size (fruit thickness and length) and weight of fruit and firmest and had the highest brix and sugar/acid ratio in 2009, whereas in 2008 they were the larger, softer with higher citric acid and chroma value. The greatest variability within the observed characteristics was found in the case of fruit detachment force, which it was significantly higher in 2008 $(3.42 \mathrm{~N})$ compare to $2009(2.14 \mathrm{~N})$. Certain differences in firmness and total acid content between the particular years could be influenced by different ripening degree as shown by Ferrandino et al. (2001).

Table 2 shows mean values and significant level for the measured factors of various cultivars. The fruit detachment force was the highest for Debreceni bőtermő cultivar (3.92 N) and was the lowest for Oblacsinszka cultivar $(1.19 \mathrm{~N})$. The highest and the lowest of fruit width observed in Csengődi (24.37 mm) and Oblacsinszka (17.63 $\mathrm{mm})$ cultivars, respectively. The highest and the lowest of fruit thickness and length observed in Pándy 279 (23.22 and $21.60 \mathrm{~mm}$ ) and Oblacsinszka (17.73 and $15.77 \mathrm{~mm}$ ), respectively.

The citric acid of Pándy 279 and Debreceni bötermö cultivars were higher than other cultivars, but it was the lowest rate in Csengődi (1.23\%) cultivar. A wide range of brix was found in Oblacsinszka and Éva cultivars. Sugar/acid ratio was determined in the lower amount in the Debreceni bötermö cultivar. Crisosto et al. (2003) expressed that brix rate is depended to cultivar and also found that high consumer acceptance was determined on 'Brooks' and 'Bing' cherries when SSC were $\geq 16.0 \%$ without regard to TA.

The highest amount of fruit and pit weight was depended to Pándy 279 (7.03 and $0.49 \mathrm{~g}$, respectively) and the lowest was depended to Oblacsinszka (3.22 and $0.25 \mathrm{~g}$, respectively). While, Érdi bőtermő had the highest flesh/pit ratio (15.88) and Oblacsinszka had the lowest flesh/pit ratio (12.10).

The highest and lowest amount of flesh firmness was depended to Pandy $279\left(578.51 \mathrm{KP} / \mathrm{mm}^{2}\right)$ and Érdi bőtermő (302.40 KP/mm²), respectively.

Simcic et al. (1998) report decrease of flesh firmness and total acids during ripening and an increment of fruit weight, soluble solids content and individual sugars content. These compounds were found in statistically significant higher amount in the Noir De Guben variety.

The apparent colour of the sour cherry cultivars was found to be statistically significant at the $0.01 \%$ probability levels. Csengődi was darkest (highest $\left.Y^{*}, 5.76\right)$ and Érdi bőtermő was lightest (lowest $\left.\mathrm{Y}^{*}, 4.71\right)$. Hue angle (colour intensity) was the highest in the Petri (42.01) and Csengödi (41.90) cultivars and was lowest in the Újfehértói fürtös (40.53) cultivar, while, chroma value (colour purity) was the highest in the Petri (0.48) and Újfehértói fürtös (0.48) cultivars and was lowest in the case of Csengödi (0.46) cultivar.

As seen in figure 1, in 2008 the highest fruit detachment force belong to Debreceni bőtermő cultivar, while in 2009 year, this cultivar had lowest fruit detachment force. This force decreased in all studied cultivars exception Érdi bőtermő, Oblacsinszka and Csengődi cultivars. There is an

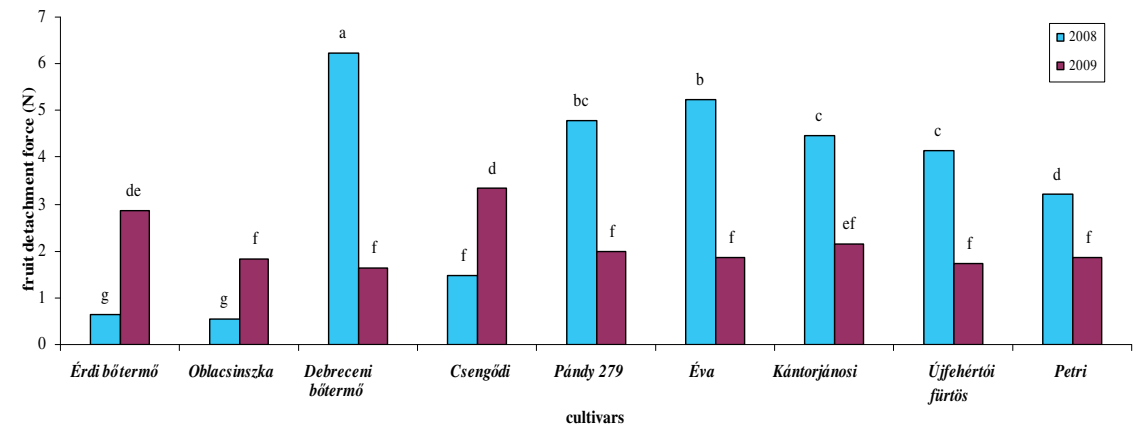

Figure 1. Fruit detachment force of the studied sour cherry cultivars in tow years (2008 \& 2009). Different letters indicate significant differences between treatments $(\mathrm{P} \leq 0.01)$. 
Table 2. Mean values of assessed characteristics and their span in nine sour cherries cultivars

\begin{tabular}{|c|c|c|c|c|c|c|c|c|c|}
\hline Cultivars & Érdi bőtermö & Oblacsinszka & $\begin{array}{l}\text { Debreceni } \\
\text { bőtermö }\end{array}$ & Csengődi & Pándy 279 & Éva & Kántorjánosi & $\begin{array}{l}\text { Újfehértói } \\
\text { fürtös }\end{array}$ & Petri \\
\hline $\begin{array}{l}\text { Fruit detachment } \\
\text { force }(\mathrm{N})\end{array}$ & $1.75^{\mathrm{f}}$ & $1.19^{\mathrm{g}}$ & $3.92^{\mathrm{a}}$ & $2.40^{\mathrm{e}}$ & $3.38^{\mathrm{bc}}$ & $3.56^{\mathrm{ab}}$ & $3.31^{\mathrm{bc}}$ & $2.93^{\mathrm{cd}}$ & $2.54^{\mathrm{de}}$ \\
\hline Fruit width (mm) & $22.72^{\mathrm{ab}}$ & $17.63^{\mathrm{c}}$ & $22.62^{\mathrm{ab}}$ & $24.37^{\mathrm{a}}$ & $23.06^{\mathrm{ab}}$ & $21.98^{\mathrm{ab}}$ & $21.59^{\mathrm{ab}}$ & $20.21^{b}$ & $21.74^{\mathrm{ab}}$ \\
\hline Fruit thickness $(\mathrm{mm})$ & $22.52^{\mathrm{b}}$ & $17.73^{\mathrm{g}}$ & $22.74^{\mathrm{ab}}$ & $19.80^{\mathrm{f}}$ & $23.22^{\mathrm{a}}$ & $22.34^{\mathrm{bc}}$ & $21.58^{\mathrm{d}}$ & $20.37^{\mathrm{e}}$ & $21.92^{\mathrm{cd}}$ \\
\hline Fruit length (mm) & $21.00^{\mathrm{b}}$ & $15.77^{\mathrm{g}}$ & $19.84^{\mathrm{cd}}$ & $21.37^{\mathrm{ab}}$ & $21.60^{\mathrm{a}}$ & $19.60^{\mathrm{de}}$ & $19.20^{\mathrm{e}}$ & $18.43^{\mathrm{f}}$ & $20.18^{\mathrm{c}}$ \\
\hline fruit weight $(\mathrm{g})$ & $6.70^{\mathrm{b}}$ & $3.22^{\mathrm{f}}$ & $6.29^{\mathrm{c}}$ & $5.86^{\mathrm{d}}$ & $7.03^{\mathrm{a}}$ & $6.00^{\mathrm{cd}}$ & $5.66^{\mathrm{d}}$ & $4.91^{\mathrm{e}}$ & $5.92^{\mathrm{d}}$ \\
\hline Peduncle length (mm) & $31.95^{\mathrm{d}}$ & $28.86^{\mathrm{e}}$ & $47.88^{\mathrm{a}}$ & $49.71^{\mathrm{a}}$ & $45.14^{\mathrm{b}}$ & $43.14^{\mathrm{bc}}$ & $43.47^{\mathrm{bc}}$ & $41.33^{\mathrm{c}}$ & $48.69^{\mathrm{a}}$ \\
\hline Firmness $\left(\mathrm{kP} / \mathrm{mm}^{2}\right)$ & $302.40^{\mathrm{e}}$ & $405.69^{\mathrm{cd}}$ & $522.03^{\mathrm{ab}}$ & $457.20^{\mathrm{d}}$ & $578.51^{\mathrm{a}}$ & $519.60^{\mathrm{ab}}$ & $538.35^{\mathrm{ab}}$ & $555.45^{\mathrm{a}}$ & $464.33^{b c}$ \\
\hline citric acid\% & $1.31^{\mathrm{e}}$ & $1.38^{\mathrm{de}}$ & $1.75^{\mathrm{a}}$ & $1.23^{\mathrm{ef}}$ & $1.82^{\mathrm{a}}$ & $1.70^{\mathrm{ab}}$ & $1.52^{\mathrm{cd}}$ & $1.37^{\mathrm{de}}$ & $1.56^{\mathrm{bc}}$ \\
\hline Brix \% & $16.35^{\mathrm{d}}$ & $18.38^{\mathrm{a}}$ & $16.35^{\mathrm{d}}$ & $15.60^{\mathrm{e}}$ & $16.23^{\mathrm{d}}$ & $18.19^{\mathrm{a}}$ & $17.36^{\mathrm{b}}$ & $16.82^{\mathrm{c}}$ & $16.48^{\mathrm{d}}$ \\
\hline pit weigh $(g)$ & $0.40^{\mathrm{c}}$ & $0.25^{\mathrm{f}}$ & $0.40^{\mathrm{c}}$ & $0.40^{\mathrm{c}}$ & $0.49^{\mathrm{a}}$ & $0.42^{\mathrm{b}}$ & $0.40^{\mathrm{c}}$ & $0.36^{\mathrm{e}}$ & $0.39 \mathrm{~d}$ \\
\hline $\mathrm{Y}^{*}$ & $4.71^{\mathrm{c}}$ & $5.10^{\mathrm{abc}}$ & $5.64^{\mathrm{ab}}$ & $5.76^{\mathrm{a}}$ & $4.86^{\mathrm{bc}}$ & $5.52^{\mathrm{abc}}$ & $5.23^{\mathrm{abc}}$ & $5.04^{\mathrm{abc}}$ & $5.54^{\mathrm{abc}}$ \\
\hline $\mathrm{x}^{*}$ & $0.35^{\mathrm{ab}}$ & $0.35^{\mathrm{ab}}$ & $0.35^{\mathrm{ab}}$ & $0.34^{\mathrm{b}}$ & $0.35^{\mathrm{ab}}$ & $0.35^{\mathrm{ab}}$ & $0.36^{\mathrm{a}}$ & $0.36^{\mathrm{a}}$ & $0.35^{\mathrm{ab}}$ \\
\hline$y^{*}$ & $0.31^{\mathrm{a}}$ & $0.31^{\mathrm{a}}$ & $0.31^{\mathrm{a}}$ & $0.31^{\mathrm{a}}$ & $0.31^{\mathrm{a}}$ & $0.31^{\mathrm{a}}$ & $0.3^{1 \mathrm{a}}$ & $0.31^{\mathrm{a}}$ & $0.32^{\mathrm{a}}$ \\
\hline Hue angle & $41.34^{\mathrm{abc}}$ & $41.32^{\mathrm{abc}}$ & $41.32^{\mathrm{abc}}$ & $41.90^{\mathrm{a}}$ & $41.17^{\mathrm{abc}}$ & $41.43^{\mathrm{abc}}$ & $40.97^{\mathrm{bc}}$ & $40.53^{c}$ & $42.01^{\mathrm{a}}$ \\
\hline Chroma value & $0.47^{\mathrm{ab}}$ & $0.47^{\mathrm{ab}}$ & $0.47^{\mathrm{ab}}$ & $0.46^{\mathrm{b}}$ & $0.47^{\mathrm{ab}}$ & $0.47^{\mathrm{ab}}$ & $0.47^{\mathrm{ab}}$ & $0.48^{\mathrm{a}}$ & $0.48^{\mathrm{a}}$ \\
\hline Flesh/pit & $15.88^{\mathrm{a}}$ & $12.10^{\mathrm{f}}$ & $14.71^{\mathrm{b}}$ & $13.58^{\mathrm{cd}}$ & $13.44^{\mathrm{de}}$ & $13.41^{\mathrm{de}}$ & $13.06^{\mathrm{de}}$ & $12.63^{\mathrm{ef}}$ & $14.41^{\mathrm{bc}}$ \\
\hline Sugar/acid & $15.16^{\mathrm{a}}$ & $15.17^{\mathrm{a}}$ & $9.35^{\mathrm{e}}$ & $13.67^{b}$ & $10.57^{\mathrm{d}}$ & $10.91^{\mathrm{d}}$ & $11.43^{\mathrm{d}}$ & $12.52^{\mathrm{c}}$ & $11.25^{\mathrm{d}}$ \\
\hline
\end{tabular}

*In each row, means with the same letters are not significantly different at $1 \%$ Level of probability using DMRT.

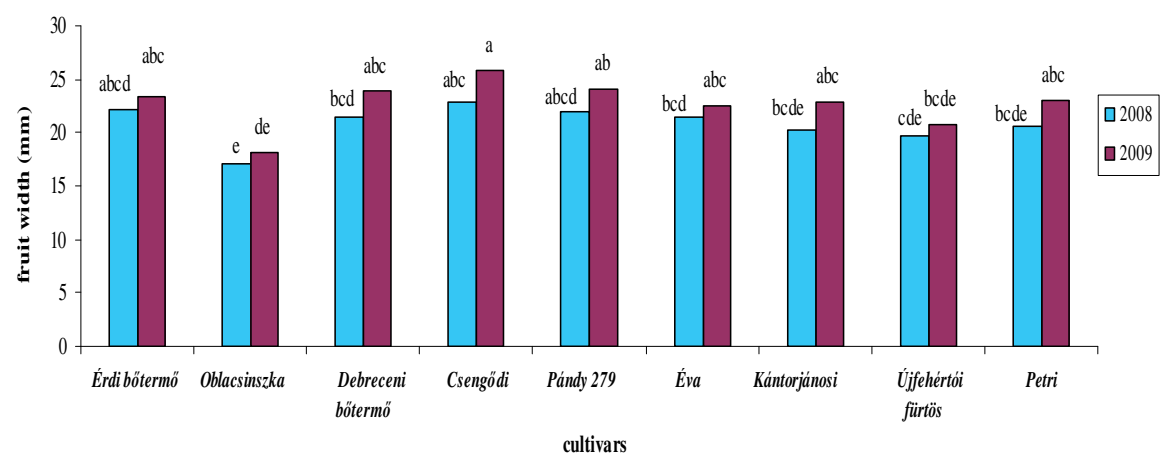

Figure 2. Fruit width of the studied sour cherry cultivars in tow years (2008 \& 2009). Different letters indicate significant differences between treatments $(\mathrm{P} \leq 0.01)$.

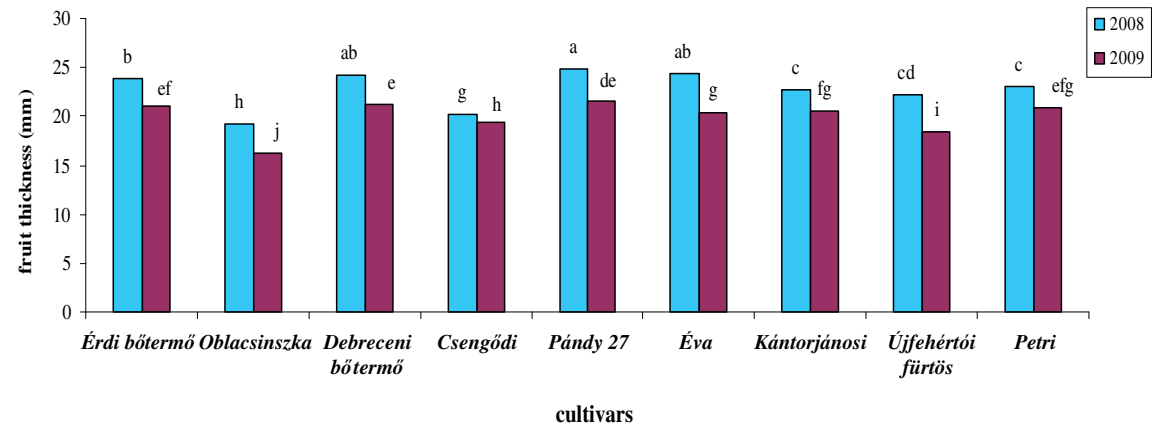

Figure 3. Fruit thickness of the studied sour cherry cultivars in tow years (2008 \& 2009). Different letters indicate significant differences between treatments $(\mathrm{P} \leq 0.01)$. abscission zone between fruit and peduncle which are very responsive to changes in the time of fruit maturity. In maturity phase, cells in this zone start to break down. A ripe fruit should separate from the peduncle with relative ease.

As shown in Figure 2, the highest and lowest fruit width was depended to Csengődi and Oblacsinszka cultivars in both years. In general, in 2009 fruit width increased than 2008. Davarynejad et al. (2009), found Újfehértói fürtös is suitable fruit for fresh consumption, but in some years the fruit size is not so desirable and fruit thinning can be profitable. As seen in figures 2, 3, 4 and 5 this cultivar in 2009 had smaller size and lower weight than 2008.

In both years, the highest and lowest fruit thickness was depended to Pándy 279 and Oblacsinszka cultivars. In general, in 2009 fruit thickness decreased than 2008 (Figure 3). The fruit size and weight extremely depend to the weather and rain fall. The average temperature and amount of 
rainfall in growing season of 2008 was 14.74 centigrade degree and $396 \mathrm{~mm}$ respectively while these parameters in 2009 changes to 15.34 and 187 . It means growing season of 2009 was warmer and the rain fall was 2 time less than 2008 .

Also, in both years, the highest and lowest fruit length was depended to Pándy 279 and Oblacsinszka cultivars. In general, in 2009 fruit thickness decreased than 2008, but in the case of Debreceni bőtermő, Kántorjánosi and Petri cultivars had no significant difference in both years (Figure 4).

In both years, the highest and lowest fruit weight belongs to Pándy 279 and Oblacsinszka cultivars. In general, in 2009 fruit thickness decreased than 2008 exception increasing in Debreceni bőtermő, Kántorjánosi and Petri cultivars (Figure 5).

As shown in Figure 6, the highest peduncle length was depended to Csengődi and Petri and lowest peduncle length belongs to Érdi bőtermő and Oblacsinszka cultivars.

The highest flesh firmness was depended to Pándy 279 in 2009 and the lowest flesh firmness was depended to Érdi bőtermő in both years and Oblacsinszka in 2008 (Figure 7).

The highest citric acid extracted from Pándy 279 in 2008 and Petri in 2009 and the lowest citric acid extracted from Érdi bőtermő in 2008 and Csengődi in 2009. In general, in 2009 citric acid decreased than 2008 (Figures 8 and 9). As shown in fig.9, the highest brix depend to Éva and Kántorjánosi in 2008 and Oblacsinszka in 2009 and the lowest brix was depended to Érdi bőtermő in 2008 and Csengődi in 2009. In general, the SSC contents were higher in the sour cherry harvested in 2009 than in those harvested in 2008. The SSC extremely changes with the weather condition. The average temperature and amount of rainfall in growing season of 2008 was 14.74 centigrade degree and 396 $\mathrm{mm}$ respectively while these parameter in 2009 changes to 15.34 and 187 . It means growing season of 2009 was warmer and the rain fall was 2 time less than 2008 . Crisosto et al. (2003) expressed that there are differences between various cultivars in SSC and TA content, such as for 'Brooks', average SSC varied from 12.8 to $21.6 \%$ and average TA changed from 0.47

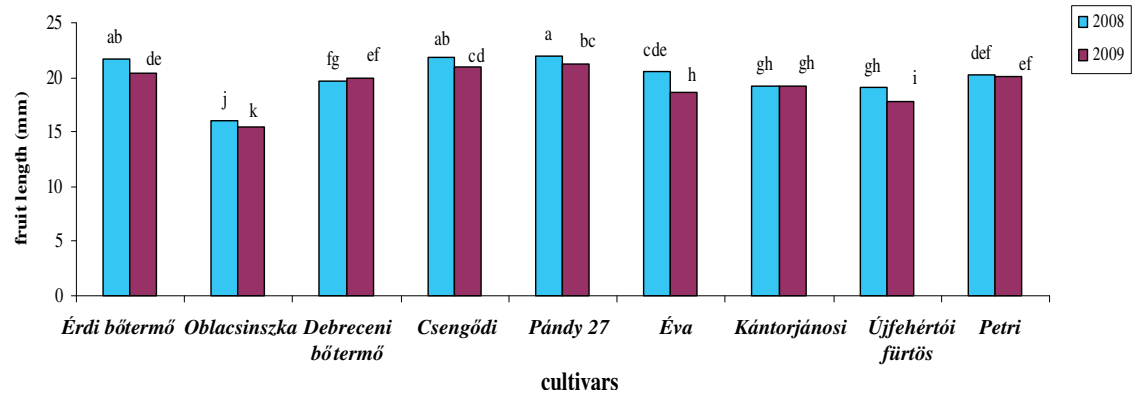

Figure 4. Fruit length of the studied sour cherry cultivars in tow years (2008 \& 2009). Different letters indicate significant differences between treatments $(\mathrm{P} \leq 0.01)$.

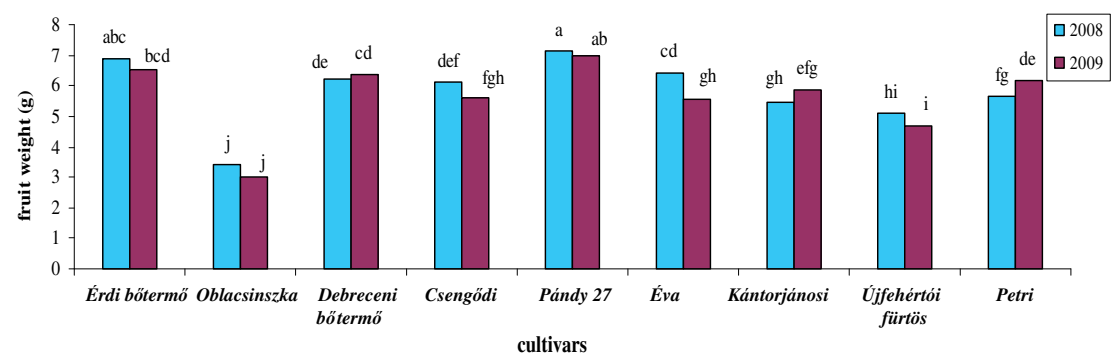

Figure 5. Fruit weight of the studied sour cherry cultivars in tow years (2008 \& 2009). Different letters indicate significant differences between treatments $(\mathrm{P} \leq 0.01)$.

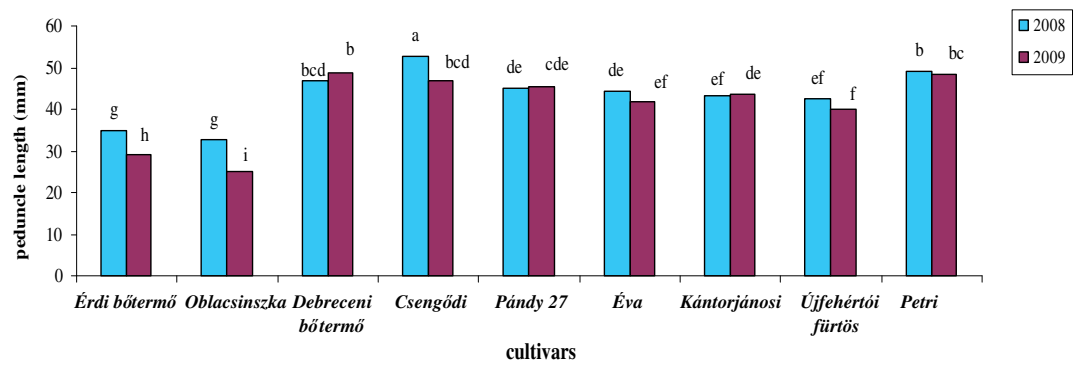

Figure 6. Peduncle length of the studied sour cherry cultivars in tow years ( $2008 \& 2009)$. Different letters indicate significant differences between treatments $(\mathrm{P} \leq 0.01)$.

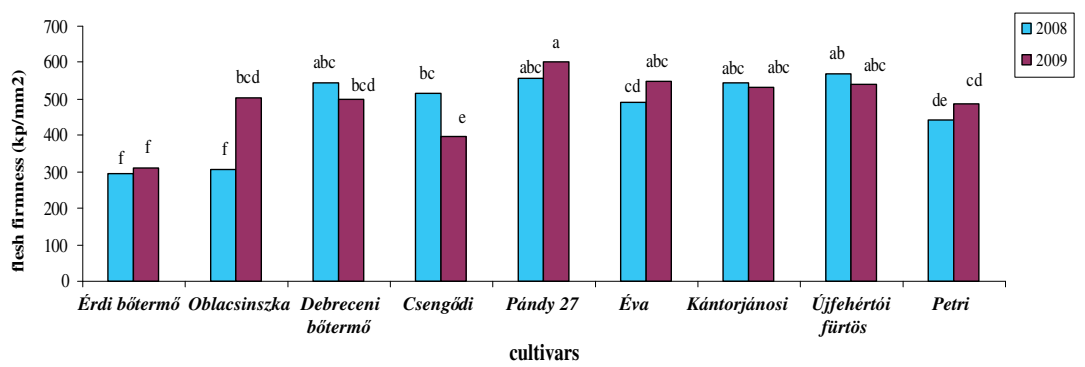

Figure 7. Flesh firmness of the studied sour cherry cultivars in tow years (2008 \& 2009). Different letters indicate significant differences between treatments $(\mathrm{P} \leq 0.01)$.

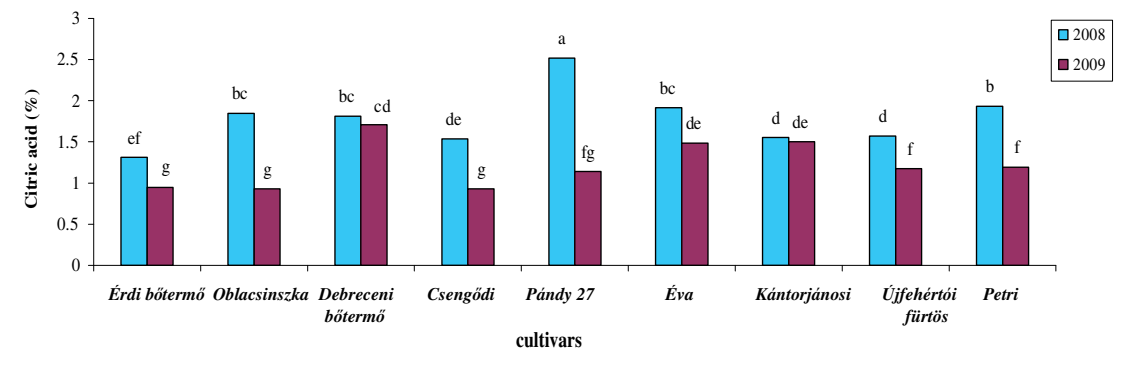

Figure 8. Citric acid of the studied sour cherry cultivars in tow years (2008 \& 2009). Different letters indicate significant differences between treatments $(\mathrm{P} \leq 0.01)$. 
to $0.67 \%$ as cherries turned from full light red to full dark red and for 'Bing', average SSC varied from 16.5 to $20.6 \%$ and average TA changed from 0.78 to $0.90 \%$ as cherries turned from salmon to dark mahogany.

The highest flesh/pit ratio was depended to Érdi bőtermő in both years and Debreceni bőtermő in 2009 and the lowest flesh/pit ratio was depended to Oblacsinszka in both years and Újfehértói fürtös in 2009 (Figure 10).

The highest sugar/acid ratio was depended to Oblacsinszka in 2009 and the lowest sugar/acid ratio was depended to Pándy 279 (Figure 11). In general, in 2009 sugar/acid ratio increased than 2008.

The majority of the differences within all the assessed colour indices between years were not statistically significant and the span values were very similar. In both cultivar and harvest date variation were differences in colour, firmness, total soluble solids, brix and titratable acidity (TA). In the opinion of Crisosto et al. (2006) soluble solids concentration (SSC) sweetness, and sourness, titratable acidity (TA) surveys, fruit flavor and aroma intensity indicate the potential fruit quality range within the industry.

The result of panel test is shown in Table 3. Consumer degree of acceptance showed that Érdi bőtermő was the best for fresh consumption. Higher consumer acceptance was attained on cultivars with a predominant flavor than other examined cultivars.

\section{Conclusions}

The results showed that the yield and fruit quality of sour cherry fruits extremely varied from year to year. In the cooler

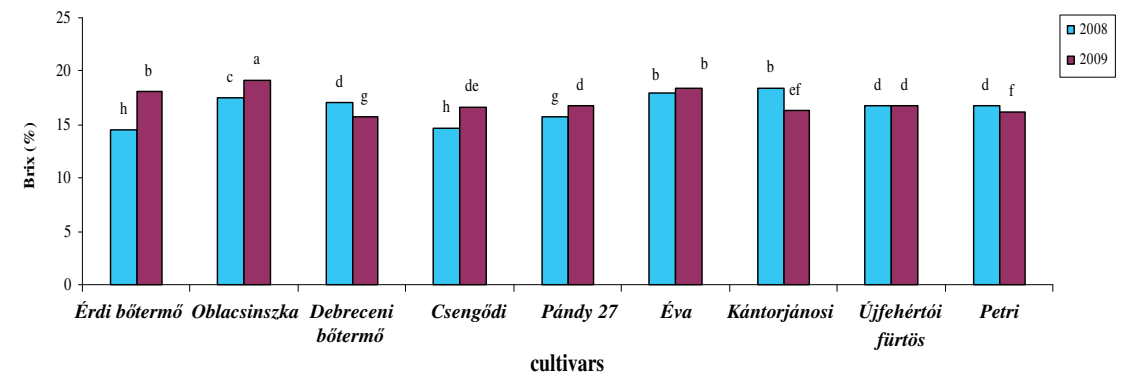

Figure 9. Brix of the studied sour cherry cultivars in tow years (2008 \& 2009). Different letters indicate significant differences between treatments $(\mathrm{P} \leq 0.01)$.

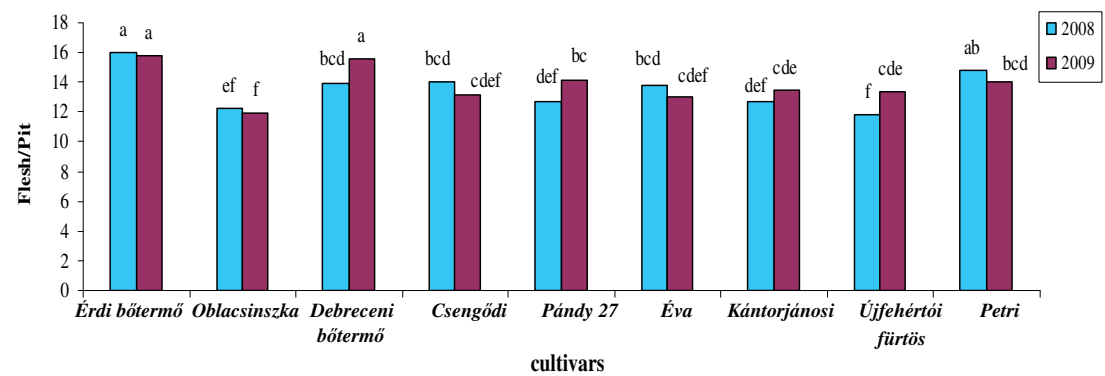

Figure 10. Flesh/Pit ratios of the studied sour cherry cultivars in tow years (2008 \& 2009). Different letters indicate significant differences between treatments $(\mathrm{P} \leq 0.01)$.

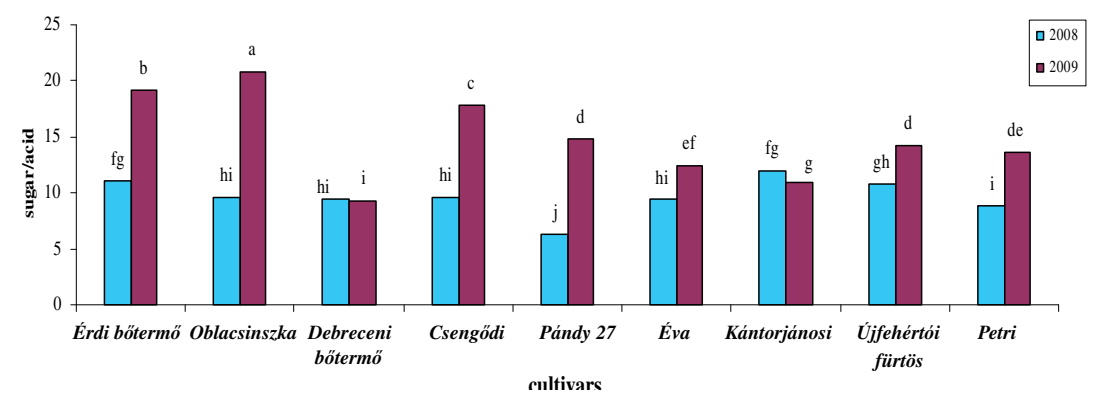

Figure 11. Sugar/acid ratios of the studied sour cherry cultivars in tow years (2008 \& 2009). Different letters indicate significant differences between treatments $(\mathrm{P} \leq 0.01)$.

and rainy years the SSC varies and show less amount of brix while the weight and size of fruit show higher degree. The average temperature and amount of rainfall in growing season of 2008 was 14.74 centigrade degree and $396 \mathrm{~mm}$ respectively while these parameter in 2009 changes to 15.34

Table 3. Panel test of sour cherry cultivars average of the years 2008-2009

\begin{tabular}{|l|c|c|c|c|c|c|c|}
\hline \multicolumn{1}{|c|}{ Cultivars } & $\begin{array}{c}\text { Flesh } \\
\text { firmness }\end{array}$ & Succulence & Sugar/acid & Aroma & Fruit presence & Flavour & General aspect \\
\hline Érdi bőtermő & 5.1 & 6.7 & 5.0 & 7.1 & 8.3 & 8.1 & 8.1 \\
\hline Oblacsinszka & 3.5 & 6.0 & 8.0 & 5.5 & 4.8 & 4.5 & 4.1 \\
\hline Debreceni bőtermö & 5.5 & 6.1 & 5.7 & 6.1 & 6.6 & 6.6 & 6.5 \\
\hline Csengödi & 4.3 & 6.9 & 6.1 & 5.3 & 6.4 & 5.7 & 6.1 \\
\hline Pándy & 5.9 & 5.7 & 6.1 & 4.9 & 6.3 & 5.7 & 5.9 \\
\hline Éva & 5.7 & 7.0 & 5.7 & 7.0 & 7.4 & 6.6 & 7.0 \\
\hline Kántorjánosi & 6.5 & 5.7 & 5.0 & 5.9 & 6.6 & 7.0 & 6.7 \\
\hline Újfehértói fürtös & 4.6 & 5.7 & 7.5 & 5.0 & 5.0 & 5.4 & 5.2 \\
\hline Petri & 5.7 & 6.5 & 6.5 & 7.0 & 6.5 & 6.8 & 6.6 \\
\hline
\end{tabular}

Comment: Panel test was done whit 15 person. Consumer degree of liking 0-9 hedonic scale ( 0 , extremely dislike, 5-neither like nor dislike and 9, like extremely) 
and 187. It means growing season of 2009 was warmer and the rain fall was 2 time less than 2008. The chromatic parameters such as $\mathrm{Y}^{*}, \mathrm{x}^{*}, \mathrm{y}^{*}$, hue angle and chroma shown that, Érdi bőtermő and Csengődi had the darkest and lightest fruit among studied cultivars, respectively. Our observations showed that for fresh consumption in the basis of fruit size, texture and flavour Érdi bőtermő $\rightarrow$ Pándy $279 \rightarrow$ Csengődi $\rightarrow$ Debreceni bőtermő $\rightarrow$ Kántorjánosi Éva $\rightarrow$ Újfehértói fürtös $\rightarrow$ Petri $\rightarrow$ Oblacsinszka and for the aim of Processing in the basis of color,acid content and size of the fruit it can be Oblacsinszka $\rightarrow$ Csengődi $\rightarrow$ Újfehértói fürtös $\rightarrow$ Kántorjánosi $\rightarrow$ Éva $\rightarrow$ Petri $\rightarrow$ Debreceni bőtermő $\rightarrow$ Pándy $279 \rightarrow$ Érdi bőtermő.

\section{References}

Ansari, M. \& Davarynejad, G.H. (2008): Marked improvement of Hungarian sour cherries by cross-polination II: Fruit quality. Asian Journal of Plant Sciences.

Childers, N.C. (1983): Modern fruit science. Hort. Publications, Gainesville, Florida, USA.

Chang, L.S. Iezzoni, A.G. \& Flore, J.A. (1987): J. Amer. Soc. Hort. Sci., 112: 247-251.

Cliff, M.A., Dever, M.C., Hall, J.W. \& Girard, B. (1996): Development and evaluation of multiple regression models for prediction of sweet cherry liking. Food Res. Int., 28: 583-589.

Crisosto, C.H. \& Crisosto, G.M. (2001): Understanding consumer acceptance of early harvested 'Hayward' kiwifruit. Postharvest Biol. Technol., 22: 205-213.

Crisosto C.H. Crisosto G. \& F. Neri (2006): Understanding Tree Fruit Quality Based on Consumer Acceptance Proc. IVth IC on MQUIC Eds. A.C. Purvis et al. Acta Hort., 712: 183-190.

Crisosto, C.H. \& Crisosto, G.M. (2002): Understanding American and Chinese consumer acceptance of 'Redglobe' table grapes. Postharvest Biol. Technol., 24: 155-162.

Crisosto, C.H., Crisosto, G.M. \& Metheney, P. (2003): Consumer acceptance of 'Brooks' and 'Bing' cherries is mainly dependent on fruit SSC and visual skin color. Postharvest Biology and Technology, 28: 159-167.

Davarynejad, G.H., Nyéki, J. Szabó T. \& Szabó, Z. (2009): Influences of hand thinning of bud and blossom on crop load, fruit characteristics and fruit growth dynamic of Újfehértói fürtös sour cherry cultivar. American-Eurasian J. Agric. \& Environ. Sci., 4. 2: 138-141.

Dever, M.C., MacDonald, R.A., Cliff, M.A. \& Lane, W.D. (1996): Sensory evaluation of sweet cherry cultivars. HortScience, 31: $150-153$.
Drake, S.R. \& Fellman, J.K. (1987): Indicators of maturity and storage quality of 'Ranier' sweet cherry. HortScience, 22: 283-285.

Ferrandino, A., Duverney, C. \& Di Stefano, R. (2001): Quality and aroma of Golden Delicious apples as influenced by the harvest date and the storage period. Acta Hort., 553: 225-227.

Gorini, F. \& Lasorella, M. (1990): Sensory and objective evaluation of kiwifruit. Acta Hortic., 282: 309-314.

Guyer, D.E., Sinha, N.K., Chang, T.S. \& Cash, J.N. (1993): Physiochemical and sensory characteristics of selected Michigan sweet cherry (Prunus avium L.) cultivars. J. Food Qual., 16: $355-370$.

Hesse, C. O. (1975): Advunce in Fruit Breeding. Purdue University Press, West Lafayette, IN.

Holb, I.J. \& Schnabel, G. (2005): Comparison of fungicide treatments combined with sanitation practices on brown rot blossom blight incidence, phytotoxicity, and yield for organic sour cherry production Plant Disease, 89: 1164-1170.

Kader, A.A. (1999): Fruit maturity, ripening, and quality relationships. In: Symposium on Effect of Pre and Post Harvest Factors on Storage of Fruit. Acta Hortic., 485: 203-208.

Rieger, M. (2003): Tart cherry juice from king orchards. February $14^{\text {th }}$ and June $2^{\text {nd }}$ Apple J., Georgia.

Girared, B. \& Kopp. T.G. (1998): Physiochemical characteristics of selected sweet cherry cultivars. Journal of Agricultural and Food chemistry, 46: 471-476.

Malundo, T.M.M., Shewfelt, R.L., Ware, G.O. \& Baldwin, E.A. (2001): Sugars and acids influence flavor properties of mango (Mangifera indica). J. Am. Soc. Hort. Sci., 126: 115-121.

Mitra, S.K., D.S. Rathore \& Bose, T.K. (1991): Temperate Fruits. Horticulture and Allied Publishers, chakraberia Lane, Calcutta, India.

Pehrson, J.E. \& Ivans, E.M. (1988): Variability in early season navel orange clone maturity and consumer acceptance. Proc. Int. Soc. Citriculture, pp. 1631-1635.

Robertson, J.A. \& Meridith, F.I. (1989): Characteristics of fruit from high- and low-quality peach cultivars. Hort. Sci., 23: $1032-1034$.

Rodan, L. (1988): Consumer acceptance of Florida grapes and grape products. Proceedings of the Viticulture Sciences Symposium Tallahassee, FL. Florida A\&M University, Center for Viticultural Sciences, p. 119-121.

Simcic, M., Zavrtanik, M. \& Hribar, J. (1998): Biochemical and morphological changes in cherries during maturation and ripening. Acta Horticulturae, 468: 725-730.

Schotzko, R.T. (1993): Fresh sweet cherry eating characteristics: some baseline data. Washington State Univ. Res. Bull., XB1028, 3-14.

Teskey, B.J.E. \& Shoemaker (1972): Tree fruit production. The AVI Publishing Company, Inc., Westport, Connecticut. 